\title{
AUTHOR, DATE, PLACE OF COMPOSITION AND ORIGINAL LANGUAGE
}

When the Persians invaded Syria in the 7 th century, the Syrian Orthodox bishop Paul of Tellā fled to Alexandria, finding refuge in one of the most famous Egyptian monasteries, Dayr al-Zajāj, later known as Dayr al-Hanațūn. ${ }^{.}$There, between 6I 3 and 6I7 CE, Paul of Tella translated into Syriac the Greek text of the Hexapla, i.e. the 'fifth' column of Origen's Hexapla, together with the Aristarchian signs. ${ }^{2}$ Although Paul of Tellā's translation, known in Syriac as shab in ("seventy"), has not survived in its entirety, ${ }^{3}$ this Syro-Hexaplar version is known to have enjoyed considerable acclaim within the Syrian Orthodox community, playing a major role both in the liturgy and

I Abū Șāliḥ al-Armanī, The Churches and Monasteries of Egypt and Some Neighbouring Countries. Edited and translated by B.T.A. Evetts, with added notes by Alfred J. Butler (Oxford: Clarendon Press, I895, reprinted Piscataway, NJ: Gorgias Press, 200I), pp. IoI (fol. 8oa, Arabic), 229 (English) and n. I. Cf. Otto F.A. Meinardus, Two Thousand Years of Coptic Christianity (Cairo - New York: The American University in Cairo Press, 2002), pp. I48-I49.

2 Timothy M. Law, 'La version syro-hexaplaire et la transmission textuelle de la Bible grecque', in L'Ancien Testament en syriaque, édité par F. Briquel Chatonnet et Ph. Le Moigne (Paris: Geuthner, 2008), pp. IOI-I20. Cf. Arthur Vööbus, The Pentateuch in the Version of the Syro-Hexapla (Leuven: Secrétariat du CorpusSCO, 1975), pp. 3-43. Cf. Peter J. Gentry, 'Hexaplaric Materials in Ecclesiastes and the Rôle of the Syro-Hexapla', Aramaic Studies I (2003), p. 7.

3 Among the new materials in Dayr al-Suryān are versions of the Books of Ezekiel (I:I-47,23) and Tobit (complete), together with fragments n. 38 and 140 corresponding respectively to Psalm 58:15-60,5 (with marginalia) and Isaiah 58:7-8, cf. S.P. Brock \& Lucas van Rompay, Catalogue of the Syriac Manuscripts and Fragments in the Library of Deir al-Suryan, Wadi al-Natrun (Egypt). "Orientalia Lovaniensia Analecta” 227 (Leuven - Paris - Walpole, MA: Peeters, 20I4), pp. 23, 45-46, 347 and 348 respectively. 
in exegesis, ${ }^{4}$ although it never replaced the Peshitttā, which had achieved the status of authorised text for Syriac-speaking Christians. ${ }^{5}$

While never earning the same renown as the Peshitttā, the importance of Paul's Syro-Hexaplar version is attested by the interlinear inclusion of variants proposed by his translation in some manuscripts of the Peshittta. A good example is MS $12 \mathrm{t}^{2}{ }^{2}$, which contains the text of the Psalms as given by the Peshitttā, accompanied by the interlinear addition of variants drawn from the Syro-Hexaplar version. ${ }^{6}$ Indeed, the fame of Paul of Tellā's translation extended beyond Syriac Orthodox circles into the Coptic Church, where reworked versions gained considerable popularity. ${ }^{7}$

The first and, as far as we know, only Arabic translation of the Pentateuch made from Paul of Tellā's Syro-Hexaplar version appears to have been produced in the Ioth century. Like its Syriac original, the Arabic text was known as sab in ("seventy", fol. $2^{\mathrm{v}}$ ). This translation, together with Arabic renderings of other Old Testament books (Proverbs, along with its prologue, Ecclesiastes, Wisdom and the Song of Songs), was attributed to al-Hārith b. Sinān b. Sunbāt (fl. gth-Ioth c. CE). ${ }^{8}$

In that sense, the hypothesis put forward by the Syrian historian and scholar Nasrallah, to the effect that this translation was made from a Greek version of the LXX, though also drawing on other versions (fait sur le texte grec des Septanta, mais

4 Willem Baars, New Syro-Hexaplaric Texts. Edited, commented upon and compared with the Septuagint (Leiden: E.J. Brill, 1968), p. 2; S.P. Brock, 'Les versions syriaques de l'Acien Testament. Quelques approaches récentes,' in L'Ancien Testament en syriaque, pp. 26-27. Cf. R.B. ter Haar Romeny, A Syrian in Greek Dress: The Use of Greek, Hebrew, and Syriac Biblical Texts in Eusebius of Emesa's Commentary on Genesis. «Tradition Exegetica Graeca» 6 (Leuven: Peeters, 1997), pp. I2I-I22; Richard J. Saley, 'The textual Vorlagen for Jacob of Edessa's Revision of the Books of Samuel', in Jacob of Edessa and the Syriac Culture of His Day, ed. R.B. ter Haar Romeny. "Monographs of the Peshitta Institute Leide" » I8 (Leiden - Boston: Brill, 2008), pp. II3-I25.

5 Bas ter Haar Romeny, 'The Syriac Versions of the Old Testament', in Sources syriaques I. Nos sources: arts et littérature syriaques, ed. Maroun Atalah et al. (Antélias, Lebanon: CERO), pp. $\mathrm{IO}_{2}-\mathrm{IO} 3$.

6 Harry F. van Rooy, 'The Syro-Hexaplaric Headings of the Psalms in Manuscript I2t3', Aramaic Studies 3:I (2005), p. I09; cf. H.F. van Rooy, 'The "Hebrew" Psalm Headings in the Syriac manuscript 12t4', Journal of Northwest Semitic Languages 25:I (1999), pp. 225237.

7 Cf. Joseph Francis Rhode, The Arabic versions of the Pentateuch in the Church of Egypt. A study from eighteen Arabic and Copto-Arabic MSS. (IX-XVII century) in the National Library at Paris, the Vatican and Bodleian Libraries and the British Museum (Washington: The Catholic University of America, 192I), pp. II, 65, 73-74.

8 Juan Pedro Monferrer-Sala, 'Una traducción árabe del Pentateuco realizada sobre la versión syro-hexaplar de Pablo de Tellā,' in Tí ínĩ xai ooí; Lo que hay entre tú y nosotros. Estudios en honor de Maria Victoria Spottorno (Córdoba: UCOPress, 2016), pp. 167-176. 
confronté à d'autres versions), ${ }^{9}$ would appear to be wholly groundless. ${ }^{\text {Io }}$ The translation attributed to al-Hārith b. Sinān b. Sunbāt was made neither from a Greek text of the Septuagint nor from Origen's Hexapla, but rather from a Syriac rendering of the Greek text of the Hexapla, ${ }^{\text {II }}$ i.e. from the Syro-Hexaplar version produced by Paul of Tella in the early 7 th century. ${ }^{\text {I2 }}$

Little is known about the translator and Bible commentator al-Hārith b. Sinān b. Sunbāt, except for what information survives regarding the translations of biblical writings attributed to him. ${ }^{\mathrm{I}} \mathrm{He}$ appears to have hailed from the well-known Mesopotamian city of Harrān, to judge by the nisbab (al-Harrānī) assigned to him by the

9 Joseph Nasrallah, 'Deux versions Melchites partielles de la Bible du IX ${ }^{\mathrm{e}}$ et du $\mathrm{X}^{\mathrm{e}}$ siècles', Oriens Christianus 64 (1980), pp. 206-210; J. Nasrallah, Histoire du mouvement littéraire dans l'église melchite du Ve au XXe siècle. Contribution à l'étude de la littérature arabe chrétienne. Vol. II. Tome 2 (750-Xe s.) (Leuven: Peeters, 1988), pp. 187-188.

Io Cf. Sidney H. Griffith, 'Les premieres versions arabes de la Bible et leurs liens avec le syriaque,' in L'Ancien Testament en syriaque, pp. 226-227; S.H. Griffith, The Bible in Arabic: The Scriptures of the 'People of the Book' in the Language of Islam (Princeton: Princeton University Press, 2013), pp. Io6-I07; J.P. Monferrer-Sala, 'Una versión árabe cristiana del texto syro-hexaplar de Pablo de Tellā. Estudio filológico de la embajada al monarca de los amorreos (Nm 21,2I-35),' Cauriensia I2 (2017), pp. 535-556; J.P. Monferrer-Sala, 'Nine PostHexaplaric Readings in the Arabic Translation of the Book of Numbers by al-Hārith b. Sinān b. Sunbāṭ (Ioth c. CE),' Zeitschrift für die altestamentlichte Wissenschaft 130/4 (2018), pp. 602-615.

II Anton Baumstark, Geschichte der syrischen Literatur. Mit ausschluß der christlichenpalästinensischen Texte (Bonn: A. Marcus y E. Wevers, 1922, reprinted in Walter de Gruyter, 1968), pp. I86-I87. See also Georg Graf, Geschichte der christlichen-arabischen Literatur, 5 vols. (Città del Vaticano: Biblioteca Apostolica Vaticana, 1944-47), I, pp. I07-108 (henceforth GCAL).

I2 Giuseppe Simone Assemani (= Yūsuf b. Sam‘ān al-Sam‘ānī), Bibliotheca Orientalis Clementino-Vaticana (Rome: Typis Sacrae Congregationis de Propaganda Fide, I719-1728), II, p. 48. Cf. Robert Holmes, Origenis Hexaplorum Vetus Testamentum Graecum cum variis lectionibus (Oxford: Clarendon Press, I798), vol. I, pp. 50-55 (chap. IV) of the digital version; Fridericus Field, Origenis Hexaplorum quae supersunt; sive veterum interpretum graecorum in totum Vetus Testamentum fragmenta. Tomus I. Prolegomena: Genesis - Esther (Oxford: Clarendon Press, i875), pp. lii-lx.

I3 Cf. G. Graf, GCAL I, p. 107 y II, p. 25I. Cf. also Ignatios Aphrem I. Barṣaum, Geschichte der syrischen Wissenschaften und Literatur. Translated from the Arabic by Georg Toro and Amill Gorgis. "Eichstätter Beiträge zum Christlichen Orient” 2 (Wiesbaden: Harrassowitz, 2012), pp. 43 and 284; cf. A. Baumstark, Geschichte der syrischen Literatur, pp. I87-I88. 
Arab-Copt polygraph Shams al-Ri'āsah, Abū l-Barakāt ibn Kabar († 1324). ${ }^{14}$ In his Miṣbāb al-zulmah ('Lamp of Darkness'), Ibn Kabar ascribes to al-Hārith the Arabic translations of four Old Testament books (Proverbs, along with its prologue, Ecclesiastes, Wisdom and the Song of Songs), based - like his Pentateuch - on Paul of Tellā's Syro-Hexaplar version: ${ }^{\text {Is }}$

$$
\text { ترجم كتب سليمان الحرث بن سنان بن سنباط الحرّانيّ }
$$

“Al-Hārith b. Sinān b. Sunbāṭ al-Harrānī translated the books of Solomon”

A passing reference to al-Hārith b. Sinān b. Sunbāṭ is also to be found in the writings of the celebrated Muslim intellectual Abū 1-Hasan al-Mas' ${ }^{6} \mathrm{u} d \bar{i}$ (d. 956), who noted that al-Hārith was from Harrān (min abl Harrān), and was a Melkite (min malkiyyat alnașāra $).{ }^{16}$ In a section of his Murüj al-dhahab ('Meadows of Gold') dealing with the holy buildings of the Sabaeans $\left(s \bar{a} b i{ }^{\prime} a b\right)^{17}$ in the city of Harrān, al-Mas' ūiñ reports that: ${ }^{18}$

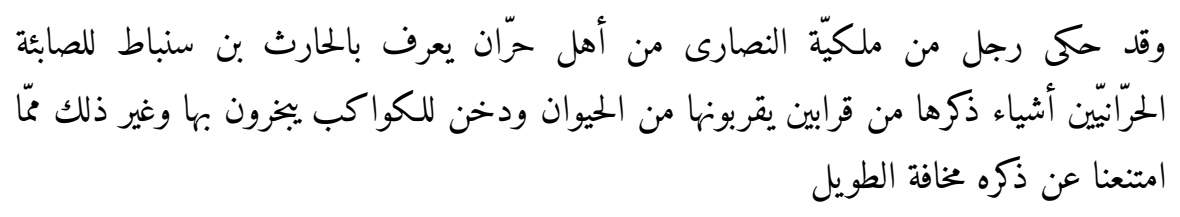

“A Melkite Christian of the people of Harrān, known as al-Hārith b. Sunbāṭ, has told us about the Sabaeans of Harrān, mentioning their sacrifice of animals, the incense

${ }^{14}$ On Ibn Kabar, cf. Eugéne Tisserant, Louis Villecourt and Gaston Wiet, 'Recherches sur la personnalité et la vie d'Abul Barakat Ibn Kubr', Revue de l'Orient Chrétien XXII (I92I22), pp. 373-394 and Samir Khalil Samir, 'L’Encyclopédie liturgique d'Ibn Kabar († 1324) et son apologie d'usages coptes', in Crossroad of Cultures. Studies in liturgy and patristics in honor of Gabriele Winkler, ed. H.-J. Feulner, E. Velkovska et R. F. Taft. "Orientalia Christiana Analecta” 260 (Rome: Pontificio Istituto Orientale, 200o), pp. 620-626. Cf. the biobibliographical information compiled by Samir Khalil Samir in his Ibn Kabar, Mișbāh alzulmah fì ị̀āḥ al-buzmah, ed. Samir Khalil (Cairo: Maktabat al-Kārūz, 197ı), pp. j-ḥ.

is Ibn Kabar, Miṣbāḅ al-zulmah, p. 236.

I6 Cf. Ignatios Aphrem I. Barșaum, Geschichte, p. 284; J. Nasrallah, Histoire du mouvement littéraire dans l'église melchite, II/2, p. I88.

${ }^{17}$ For Ṣābi'ah/Ṣābi'ūn, see Kevin T. van Bladel, From Sasanian Mandaeans to Șābians of the Marshes (Leiden-Boston: Brill, 2017).

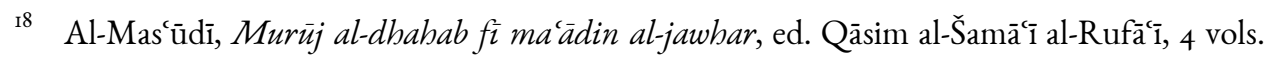
(Beirut: Dār al-Qalam, I408/1989), II, p. 253. 
which they burn to the stars, and other [practices] which we shall omit for fear of being long-winded".

The information provided by al-Mas' ${ }^{\mathrm{u}} \mathrm{d} \overline{\mathrm{i}}$ is not without doctrinal interest, since to date it has widely been accepted that al-Ḥārith b. Sinān b. Sunbāṭ was a Miaphysite, i.e. Syrian Orthodox, writer. ${ }^{19}$ This is the view recently canvassed by Vollandt, adducing internal arguments based on al-Hārith's translations. ${ }^{20}$ The link between al-Hārith and the Syrian Orthodox Church derives largely from Graf, who - ignoring the information provided by al-Mas $\overline{\mathrm{u}}^{\mathrm{i}} \overline{\mathrm{l}}^{2 \mathrm{I}}$ - simply followed the ecclesiastical classification of writers made earlier by Baumstark. ${ }^{22}$ By contrast, Nasrallah, on the basis of alMas'ūî̉’s report, identifies al-Hārith b. Sinān b. Sunbāṭ as a Melkite author. ${ }^{23}$

Though it counters the internal arguments recently adduced by Vollandt, Nasarallah's hypothesis has a number of strengths which are not to be lightly dismissed; one is that al-Hārith's translation of the Pentateuch circulated primarily in Melkite rather than Syrian Orthodox circles, ${ }^{24}$ as indeed did the Syro-Hexaplar version. ${ }^{25}$

Admittedly, Harrān had for centuries been home to a sizeable Syrian Orthodox community; but it was also a major Melkite centre, ${ }^{26}$ boasting its own Melkite bishopric whose best-known occupant was undoubtedly Theodore Abū Qurrah of Edessa. This celebrated apologist and polemicist, one of the great Christian Arab mutakka-

19 20 Christian and Muslim Sources. "Biblia Arabica" 2 (Leiden - Boston: Brill, 20I5), pp. 6o-62; R. Vollandt, 'Die Bible in der Sprache des Korans: Die arabischen Bibelübersetzungen', in Orientalische Bibelhandschriften aus der Sttatsbibliothek zu Berlin - PK. Eine illustrierte Geschichte, ed. Meliné Pehlivanian, Christoph Rauch and R. Vollandt (Wiesbaden: Reichert Verlag, 2016), p. 130; R. Vollandt, 'The Conundrum of Scriptural Plurality: The Arabic Bible, Polyglots, and Medieval Predecessors of Biblical Criticism', in The Text of the Hebrew Bible and Its Editions: Studies in Celebration of the Fifth Centennial of the Complutensian Polyglot, ed. Andrés Piquer Otero et al. (Leiden - Boston: Brill, 20I7), p. 68.

2I Cf. G. Graf, GCAL I, p. I07; II, p. 25I.

22 Cf. A. Baumstark, Geschichte der syrischen Literatur, pp. I87-188.

${ }^{23}$ Cf. J. Nasrallah, 'Deux versions Melchites partielles de la Bible du IX ${ }^{\mathrm{e}}$ et du $\mathrm{X}^{\mathrm{e}}$ siècles', Oriens Christianus 64 (1980), pp. 206-210; J. Nasrallah, Histoire du mouvement littéraire dans l'église melchite, II/2, pp. 187-188.

24 Cf. R. Vollandt, Arabic Versions of the Pentateuch, p. 62

25 Cf. W. Baars, New Syro-Hexaplaric Texts, p. 2, n. 2.

${ }^{26}$ Hugh Kennedy, 'The Melkite Church from the Islamic Conquest to the Crusades: Continuity and Adaptation in the Byzantine Legacy', in The I7th International Byzantine Congress: Major Papers (New Rochelle, NY: Caratzas, 1986), p. 337. 
limūn, held the post of Bishop of Harrān in the mid-9 ${ }^{\text {th }}$ century $\mathrm{CE}^{27}$ Even so, further research and new data are required in order to finally determine whether al-Hārith $b$. Sinān b. Sunbāt belonged to the Melkite or the Syrian Orthodox Church.

Nor, given the paucity of biographical information, can we be sure exactly where al-Hārith produced his Arabic rendering of Paul of Tellā's Greek-to-Syriac translation of the Pentateuch, various reworkings of which later entered circulation. If the reference supplied by al-Mas' $\overline{\text { ù }}$ is reliable, it would be reasonable to assume that the translation was made in the city of Harrān, in Upper Mesopotamia.

The diplomatic edition presented here is that of Sinai Arabic 3, a codex on Oriental paper measuring $25 \times 17.5 \mathrm{~cm}$., comprising 373 fols., with 5 bifolia per quire. ${ }^{28}$ The text block comprises 17 lines per page in nask $h \bar{\imath}$ script with sporadic vocalisation and rubricated chapter headings. The MS is made up of 305 quires, quire order being indicated by ordinal numbering in the top left margin of the recto. The second quire is in fol. $32{ }^{\mathrm{r}}$. Foliation is indicated in cursive Coptic numerals. ${ }^{29}$

The manuscript was written by a deacon (shammās) named Yūsūf ibn Subāt alĀmadī al-Suryānī and bears a date equivalent to $1348 \mathrm{CE}$. This is confirmed in the colophon to the books of the Pentateuch (fols. $330^{\mathrm{v}}-33 \mathrm{I}^{\mathrm{r}}$ ), which additionally state that the text was translated into Arabic from Syriac and Hebrew:

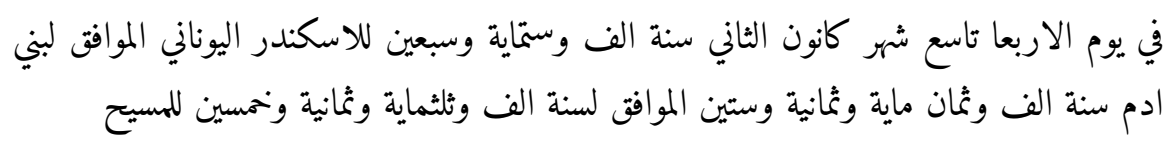

"On Wednesday 9 Känūn al-Thāni, year 1670 of the Seleucid Era, ${ }^{30}$ corresponding to the year 6868 of the Creation (Era), ${ }^{31}$ corresponding to the year 1358 of the Common Era." 32

${ }^{27}$ For the biography of Abū Qurrah and the famous incident of his dismissal from the bishopric and subsequent restoration, see S.H. Griffith, Theodore Abü Qurrab: The Intellectual Profile of an Arab Writer of the First Abbasid Century (Tel Aviv: Tel Aviv University, 1992), pp. $15-35$.

28 Cf. Aziz Suryal Atiya, The Arabic Manuscripts of Mount Sinai: A Hand-list of the Arabic Manuscripts and Scrolls Microfilmed at the Library of the Monastery of St. Catherine, Mount Sinai (Baltimore, MD: The Johns Hopkins Press, 1955), p. 3.

29 On this system, cf. Serge Frantsouzoff, 'Les chiffres coptes dans les manuscrits árabes, chrétiens et musulmans', Parole de l'Orient 39 (2014), pp. 259-273, and J.P. Monferrer-Sala, "Dos tablas inéditas con alfabeto copto y cifras coptas cursivas insertas en un códice del s. XIII del Monasterio de Santa Catalina, Monte Sinaí”, Collectanea Christiana Orientalia $\mathbf{I 2}$ (2015), pp. 279-286.

30 Lit. 'of the Alexander the Ionian'.

${ }^{3}$ L Lit. 'of the sons of Adam'.

32 Lit. 'of Christ'. 
The text transmitted by Sinai Arabic 3 is part of a textual corpus produced from the ${ }_{13}{ }^{\text {th }}$ century onwards. The version of the Pentateuch, as we shall see, is the fruit of a revision of al-Hārith's translation, if not of a later version of it. The revised text has been preserved in a group of manuscripts of predominantly Melkite provenance. ${ }^{33}$

Sinai Arabic 3 includes two different types of text: the Pentateuch, which is a revision of the translation made by al-Hārith b. Sinān b. Sunbāț; and the sixth book in the Hexateuch, a version of the Book of Joshua whose Vorlage - unlike the other five books in the Codex - is not a Syro-Hexaplar text, but probably another Syriac text which was checked or revised against other versions. As we shall see later, if the Peshịttā was not the basic text used in this translation, it may well have been used for verification purposes.

As noted earlier, it is not known where al-Hārith b. Sinān b. Sunbāṭ made his original translation of the Pentateuch; by contrast, Sinai Arabic 3 provides key information regarding the transmission of the Codex. The copyist indicates on fol. $2^{\mathrm{r}}$ that the Codex belonged to one 'İsā b. Sa'īd al-Ṭabīb, a person described as living 'in a city of Syria' (bi-madinat Shäm), for which no name is given. ${ }^{34}$

A note on fol. $33 \mathrm{I}^{\mathrm{r}}$, where the owner is referred to as Shaykh Abū l-Faḍā'il Sharaf al-Dawlah 'İsā ibn Sa'īd al-Mutațabib, states that the manuscript was an Arabic translation from Syriac and Hebrew, adding:

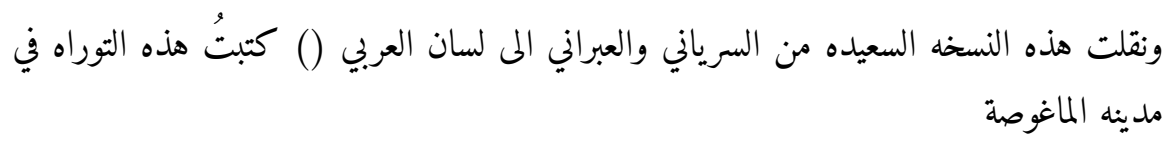

"This lucky copy was translated from Syriac and Hebrew into Arabic tongue (...) I copied this Pentateuch in the city of Famagusta"

Still on fol. $33^{\mathrm{r}}{ }^{\mathrm{T}}$, the copyist Yūsūf ibn Subāt al-Āmadī al-Suryānī notes not only that he made the copy in the city of Famagusta, but also that it was commissioned by Shaykh Abū l-Faḍā'il Sharaf al-Dawlah 'Īsā ibn Sa'īd al-Mutațabbib, a native of Baghdad (min abl Baghdād), who was living on the Island of Cyprus (Jazirat Qubrus), which at the time provided a natural channel for books destined for the library at St. Catherine's monastery on Mount Sinai. ${ }^{35}$

33 Cf. R. Vollandt, Arabic Versions of the Pentateuch, pp. 260-264.

34 Cf. R. Vollandt, Arabic Versions of the Pentateuch, p. 260.

35 Cf. J.P. Monferrer-Sala, 'An Arabic gospel of Cypriot origin: Codex arabicus sinaiticus IIo,' Graeco-Arabica (= Festschrift in Honour of V. Christides), IX-X (2004), pp. 28I-289. 
